\title{
An International Perspective on Real Estate Research Priorities
}

Executive Summary. Surveys of real estate research priorities for real estate fund managers in the United States, United Kingdom, Australia and Germany over 2000-03 are examined. Thirty-nine real estate research priorities are assessed, with much closer alignment for real estate research priorities in the U.K., Germany and Australia than seen for the U.S. The role of real estate in a mixed-asset portfolio and real estate and portfolio risk management figure prominently amongst the general real estate research priorities. The top specific real estate research priorities were the impact of capital flows, real estate cycles and real estate portfolio diversification. The underlying general real estate research priorities " $d i$ mensions" highlight the strategic issues involved in real estate research, particularly the changing real estate environment, strategic real estate issues and the role of real estate in the portfolio.

\footnotetext{
*University of Western Sydney, Australia or g.newell@ uws.edu.au.

**University of San Diego, San Diego, CA $92110-2492$ or eworzala@sandiego.edu.

***University of Reading, U.K. or p.m.mcallister@reading. ac.uk.

****European Business School, Germany or schulte.ebs@tonline.de.
}

by Graeme Newell*

Elaine Worzala**

Patrick McAllister***

Karl-Werner Schulte ${ }^{* * * *}$

\section{Introduction}

Real estate research has taken on increased importance in recent years in the international arena. The establishment of the regional real estate societies (particularly ARES, ERES, PRRES and AsRES) and their annual conferences have been key catalysts to this expanded real estate research agenda, with much of this research having a strong real estate industry focus. As such, general real estate research areas have been identified by leading real estate academics in the United States and the United Kingdom (Lusht, 1993; Webb, 1997; Jaffe, 1998; Crosby, 2000; Worzala, 2002; and Adair, Crosby, Lim and Watkins, 2003), as well as by leading U.S. and Australian real estate practitioners (Winograd, 1999; Souza, 2000; Parker, 2001; and Steinert and Crowe, 2001).

To more fully assess the real estate research directions and priorities for U.S. institutional investors, extensive real estate industry surveys have been funded by the National Council of Real Estate Investment Fiduciaries (NCREIF) in 1992 (Ziering and Worzala, 1997) and the Pension Real Estate Association (PREA) in 2000 (Worzala, Gilliland and Gordon, 2002), with Newell, Acheampong and Worzala (2002) conducting an equivalent real estate research priorities survey for Australia in 2001. In 2003, equivalent real estate research priority surveys have been conducted in the U.K. (Newell, McAllister and Worzala, 2003) and Germany (Schulte, Newell and Worzala, 2003). 
Given these significant international real estate research developments, the purpose of this research is to compare the results of these four recent major international real estate surveys to examine the real estate research priorities of real estate fund managers in the U.S., U.K., Australia and Germany. Identification of these real estate research priorities will enable the more effective development of a real estate research agenda for real estate researchers in ARES, ERES, PRRES and AsRES, as well as for the emerging real estate societies of AfRES and LaRES.

\section{Methodology}

\section{Surveys}

Separate questionnaires involving general and specific real estate research topics for real estate fund managers were conducted in U.S. (Worzala et al., 2002), Australia (Newell et al., 2002), U.K. (Newell et al, 2003) and Germany (Schulte et al., 2003). From these four surveys conducted over 2000-03, twelve general real estate research topics and twenty-seven specific real estate research topics were common to all four surveys and form the basis for the survey analysis in this research. For these thirty-nine research topics, only slight changes in wording were used in the four surveys to accommodate differences in local real estate terminology. ${ }^{1}$ The earlier 1992 U.S. survey (Ziering and Worzala, 1997) was not included in this comparative study as the twenty-seven specific real estate research topics were not included and only a subset of the twelve general real estate research topics were involved.

Real estate fund managers were asked to assess how important they believed each real estate research topic was. All questions were scored on a five-point rating scale, ${ }^{2}$ ranging from $1=$ "not important" to 5 = "vitally important."

Exhibit 1 gives details of the survey respondents in these four real estate fund manager surveys. Depending on the survey, 30-79 real estate fund managers participated in each survey, with a total of 227 respondents across the four surveys. ${ }^{3}$

\section{Exhibit 1 \\ Real Estate Fund Manager Survey Respondent Profiles}

\section{U.K.}

Survey conducted: February 2003

Survey respondents analyzed: 79 fund managers

Total survey respondents: 274 , including real estate fund managers, real estate advisors and consultants, real estate companies, real estate academics.

\section{Australia}

Survey conducted: October 2001

Survey respondents analyzed: 59 fund managers

Total survey respondents: 96, including real estate fund managers, real estate advisors and consultants, real estate companies, real estate academics.

\section{Germany}

Survey conducted: March 2003

Survey respondents analyzed: 30 fund managers

Total survey respondents: 90 , including real estate fund managers, real estate advisors and consultants, real estate companies.

U.S.

Survey conducted: Fall 2000

Survey respondents analyzed: 59 fund managers

Total survey respondents: 59

Focused on the research needs of the institutional investor, broader real estate research topics relevant to other groups (e.g., housing, real estate development) were not considered in these surveys.

\section{Statistical Analysis}

Average ratings for each of the thirty-nine general and specific real estate research topics were assessed for each of the four countries surveyed. Correlations were used to compare the real estate research priorities from the four country surveys.

To assess the underlying real estate research "dimensions" in the twelve general real estate research topics and the twenty-seven specific real estate research topics, principal component analysis (Everitt and Dunn, 2001) was applied to the four groups of respondents. Principal component analysis (PCA) is a multivariate analysis technique in which the underlying dimensions in the survey data are examined. Typically, a small number of dimensions are extracted that explain a significant 
proportion of the total variation. A practical "real estate" interpretation can often be given to these major underlying dimensions, although meaningful interpretations are often not possible for the less significant dimensions.

\section{General Real Estate Research Priorities}

\section{Analysis of General Real Estate Research Priorities}

Exhibit 2 presents the average scores and respective ranks for the twelve general real estate research topics for the U.S, Australia, Germany and U.K. real estate fund manager surveys.

While differences occurred amongst the four surveys, the top four general real estate research priorities were:

1. The role of real estate in a mixed-asset portfolio;

2. Real estate and portfolio risk management;

3. Performance measures for real estate; and

4. Diversification within real estate portfolios.

In particular, the role of real estate in a mixedasset portfolio was ranked first in the U.K. and
Australia surveys, and was in the top four priorities for the corresponding U.S. and Germany surveys.

The low priority given to the role of international real estate in a portfolio in the U.S., U.K. and Australia surveys was surprising, given the significant recent institutional interest in incorporating international real estate in real estate portfolios, particularly via indirect real estate investments such as real estate investment trusts (REITs) and listed property trusts (LPTs) (Steinert and Crowe, 2001).

The high priority given to the role of international real estate in a portfolio in the Germany survey (ranked second) reflects the more flexible foreign investment legislation (Fourth Financial Market Promotion Act) introduced in Germany in July 2002. This sees the previous restriction on nonEuropean Economic Area investment of a maximum $20 \%$ of fund assets replaced by a "currencyrisk" ceiling of $30 \%$ of fund assets. This has resulted in considerable recent activity by German funds (e.g., Deka Immobilien Investment $\mathrm{GmbH}$ and DIFA Deutsche Immobilien Fonds AG) in acquiring commercial real estate in the U.S. (Jones Lang LaSalle, 2002), with over $\$ 5$ billion invested

Exhibit 2

General Real Estate Research Priorities

\begin{tabular}{|c|c|c|c|c|c|c|c|c|}
\hline \multirow[b]{2}{*}{ General Real Estate Research Topic } & \multicolumn{2}{|l|}{ U.K. } & \multicolumn{2}{|c|}{ Australia } & \multicolumn{2}{|c|}{ Germany } & \multicolumn{2}{|l|}{ U.S. } \\
\hline & Score & Rank & Score & Rank & Score & Rank & Score & Rank \\
\hline The role of real estate in a mixed-asset portfolio & 4.06 & 1 & 4.14 & 1 & 4.00 & 4 & 3.66 & 3 \\
\hline Macroeconomic factors affecting real estate & $\mathbf{3 . 8 7}$ & $\mathbf{2}$ & 3.80 & 6 & 3.83 & 6 & 3.38 & 9 \\
\hline Real estate and portfolio risk management & 3.85 & 3 & 4.02 & 2 & 4.23 & 1 & 3.55 & 7 \\
\hline Indirect real estate investment vehicles & 3.72 & 4 & 3.69 & 7 & 3.73 & 8 & 3.36 & 10 \\
\hline Regulatory changes affecting real estate & 3.69 & 5 & 3.51 & 9 & 3.20 & 10 & 3.06 & 12 \\
\hline Diversification within real estate portfolios & 3.65 & 6 & 3.83 & 4 & 4.00 & 4 & 3.62 & 5 \\
\hline Performance measures for real estate & 3.59 & 7 & 4.00 & 3 & 4.07 & 3 & 4.07 & $\mathbf{1}$ \\
\hline Real estate investment strategies & 3.45 & 8 & 3.83 & 4 & 3.37 & 9 & 3.52 & 8 \\
\hline Microeconomic factors affecting real estate & 3.39 & 9 & 3.53 & 8 & 3.80 & 7 & 3.89 & 2 \\
\hline Demographic changes affecting real estate & 3.18 & 10 & 3.46 & 10 & 3.07 & 11 & 3.65 & 4 \\
\hline Technological changes affecting real estate & 3.06 & 11 & 3.25 & 12 & 3.07 & 11 & 3.60 & 6 \\
\hline Role of international real estate in a portfolio & 2.77 & 12 & 3.36 & 11 & 4.10 & 2 & 3.23 & 11 \\
\hline Overall average score & 3.52 & & $\mathbf{3 . 7 0}$ & & 3.71 & & 3.55 & \\
\hline
\end{tabular}

Note: The top three priorities for each country are in boldface type. 
by German funds in U.S. commercial real estate over January 2002-May 2003. Other factors influencing this high priority in the German survey for international real estate investments include the introduction of the Euro as the common European currency, effectively eliminating exchange rate risk for German real estate investors in Europe.

The major differences between the U.S. survey and the U.K., Australia and Germany surveys were the higher U.S. priority given to microeconomic factors affecting real estate and demographic changes affecting real estate. Similarly, a lower U.S. priority was given to real estate and portfolio risk management.

The extent of these differences in general research priorities is shown in the cross-country correlations detailed in Exhibit 3. The U.S. priorities were not significantly correlated with any of the U.K., Australia and Germany priorities (average correlation $=0.21$, compared to an average direct correlation of 0.59 across the U.K., Australia and Germany surveys. The highest significant correlations were for the Australia/U.K. (correlation $=0.81$ ) and Australia/Germany (correlation $=0.61$ ) priorities.

A range of factors are likely contributors to the differences between the U.S. and the U.K., Australia and Germany surveys. These factors include:

- The large and self-contained nature of the U.S. real estate market, compared to the strong linkages and communication between U.K. firms in Germany and German banks in the U.K.; similarly with the strong

\section{Exhibit 3}

General Real Estate Research Priorities: Cross-Country Correlations

\begin{tabular}{lllll}
\hline & U.K. & Australia & Germany & U.S. \\
\hline U.K. & 1.00 & & & \\
Australia & $0.81^{*}$ & 1.00 & & \\
Germany & 0.34 & $0.61^{*}$ & 1.00 & \\
U.S. & 0.06 & 0.34 & 0.23 & 1.00 \\
\hline Note: & & & \\
* Significant correlation $(p<5 \%)$. & & \\
\hline
\end{tabular}

economic and business linkages between the U.K. and Australia;

- The strong reliance by U.S. institutional investors on a sophisticated advisory and investment management industry (e.g., Jones Lang LaSalle) to have detailed real estate expertise, compared to the typically "inhouse" expertise scenario for the U.K. and Australia;

- U.K. and Australian institutional investors have historically held significantly more real estate in their portfolios than their U.S. equivalents; this typically results in more institutional familiarity with real estate as an asset class than seen for real estate managers in U.S. pension funds;

- U.K., German and Australian institutional investors have a longer history of investing in real estate than their U.S. equivalents; this further reinforces their institutional familiarity with real estate as an asset class; and

- Real estate fund managers in the U.S. have not necessarily been formally trained in the real estate discipline, often being CFAaccredited compared to having real estate or finance degree backgrounds, whereas their equivalents in the U.K. are typically trained in RICS-accredited real estate degree programs. This difference in educational background has significant implications for understanding real estate as an asset class.

\section{Identifying Dimensions in General Real Estate Research Priorities}

Using principal component analysis, from the twelve general real estate research topics, Exhibit 4 indicates the number of underlying real estate "dimensions" and level of total variation explained for the four surveys, with Exhibit 5 presenting the PCA factor weights for the underlying dimensions for the U.K., Australian, German and U.S. analyses of the general real estate research priorities. The PCA results were generally consistent, identifying four or five real estate dimensions and accounting for $63.7 \%-70.2 \%$ of the total variation in each case. 


\section{Exhibit 4 \\ General Real Estate Research Priorities: PCA Dimensions}

\footnotetext{
U.K.: Four Dimensions Accounting for $\mathbf{6 3 . 7 \%}$ of Variation

1. Changing real estate environment (18.0\%)

2. Strategic real estate issues (17.9\%)

3. Economic environment (15.1\%)

4. Role of real estate in portfolio (12.7\%)
}

\section{Variation \\ 1. Changing real estate environment (21.1\%) \\ 2. Strategic real estate issues (13.5\%) \\ 3. Role of real estate in portfolio (13.4\%) \\ 4. Macro real estate issues (10.9\%) \\ 5. Micro real estate issues $(10.1 \%)$}

Australia: Five Dimensions Accounting for $69.1 \%$ of

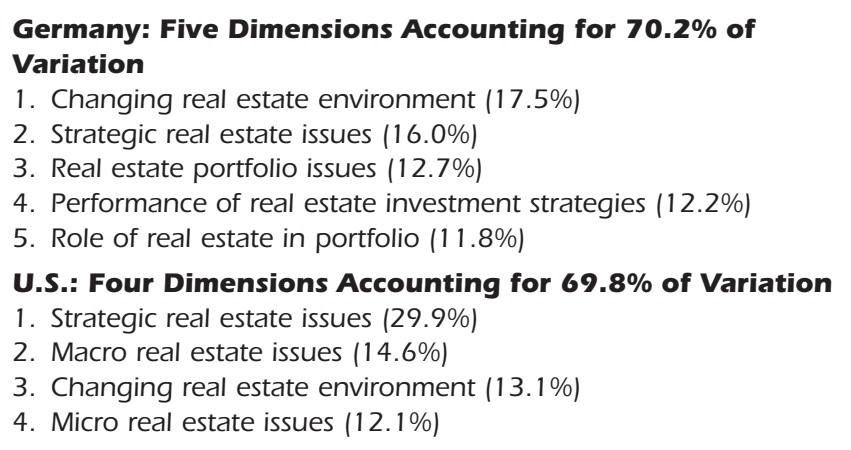

All dimensions from each real estate fund manager survey were readily interpreted in a real estate context. The real estate dimensions that dominated across the four surveys were:

1. Changing real estate environment;

2. Strategic real estate issues; and

3. Role of real estate in portfolio.

These dimensions reflect the broad, strategic issues relating to real estate research. In particular, the changing real estate environment was the dominant real estate dimension in all surveys (except the U.S. survey), accounting for $13.1 \%-21.1 \%$ of the total variation explained. This further reinforces the differences between the U.S. survey and the U.K., Australia and Germany surveys.

\section{Specific Real Estate Research Priorities}

\section{Analysis of Specific Real Estate Research Priorities}

The average scores and respective ranks for the twenty-seven specific real estate research topics for the U.K., Australia, Germany and U.S. real estate fund manager surveys are shown in Exhibit 6. Compared to the general real estate research priorities, there was considerably more variation in the specific real estate research priorities across the surveys of the four countries. This was evident in that no specific real estate research topic was ranked in the top four priorities in more than $50 \%$ of the surveys.

Across the four surveys, the top six specific real estate research priorities were:

1. Impact of capital flows in and out of real estate markets;

2. Existence and predictability of real estate cycles;

3. Diversification within a mixed-asset portfolio; and

4. Diversification within a real estate portfolio.

5. Forecasting methodologies for markets, results, returns; and

6. Real estate disposal and exit strategies.

The other topic that ranked highly across individual surveys was taxation factors affecting real estate (U.K. and Germany). The lower priority given to taxation factors in the U.S. and Australia surveys reflect the significant role of REITs in the U.S. and LPTs in Australia, with both having taxexempt status.

Specific real estate research priorities average scores in each survey were lower than that seen for the general real estate research priorities average scores, reflecting the higher priority given by real estate fund managers to the broader strategic real estate issues, rather than the more specific real estate topics.

The extent of the differences in these specific real estate research priorities is shown in the crosscountry correlations in Exhibit 7. Significant correlations are seen between the U.K., Australia and Germany specific priorities (average correlation = $.56)$, with no significant correlations seen for the U.S. specific priorities with each of the U.K., Australia and Germany survey priorities (average correlation $=.18$ ). This lesser correlation with the U.S. survey results for the specific real estate 


\section{Exhibit 5}

\section{PCA Factor Weights for General Real Estate Research Priorities}

\begin{tabular}{|c|c|c|c|c|c|}
\hline \multirow[b]{2}{*}{ Topic } & \multicolumn{5}{|c|}{ Dimensions } \\
\hline & 1 & 2 & 3 & 4 & 5 \\
\hline \multicolumn{6}{|c|}{ Panel A: U.K.: Four dimensions accounting for $63.7 \%$ of variation } \\
\hline The role of real estate in a mixed-asset portfolio & .01 & .63 & -.20 & .40 & \\
\hline Diversification within real estate portfolios & .21 & .77 & .04 & .12 & \\
\hline Macroeconomic factors affecting real estate & .20 & .04 & .79 & .20 & \\
\hline Microeconomic factors affecting real estate & .00 & .05 & .83 & -.03 & \\
\hline Performance measures of real estate & .04 & .56 & .56 & -.08 & \\
\hline Role of international real estate in a portfolio & -.14 & .22 & .06 & .76 & \\
\hline Real estate and portfolio risk management & -.27 & .55 & .12 & .30 & \\
\hline Indirect real estate investment vehicles & .39 & -.04 & .07 & .75 & \\
\hline Demographic changes affecting real estate & .80 & -.02 & .17 & .03 & \\
\hline Technological factors affecting real estate & .78 & .05 & .05 & .12 & \\
\hline Regulatory changes affecting real estate & .74 & .15 & .01 & -.05 & \\
\hline Real estate investment strategies & .21 & .67 & .29 & -.27 & \\
\hline Percentage variation explained & $25.1 \%$ & $16.0 \%$ & $12.9 \%$ & $9.8 \%$ & \\
\hline Cumulative percentage variation explained & $25.1 \%$ & $41.1 \%$ & $54.0 \%$ & $63.7 \%$ & \\
\hline \multicolumn{6}{|c|}{ Panel B: Australia: Five dimensions accounting for $69.1 \%$ of variation } \\
\hline The role of real estate in a mixed-asset portfolio & -.06 & .22 & .76 & .09 & .02 \\
\hline Diversification within real estate portfolios & -.17 & .84 & .17 & -.05 & .04 \\
\hline Macroeconomic factors affecting real estate & .21 & .17 & .12 & .75 & .21 \\
\hline Microeconomic factors affecting real estate & .37 & -.06 & .08 & .36 & .65 \\
\hline Performance measures of real estate & .21 & .01 & .09 & .06 & -.78 \\
\hline Role of international real estate in a portfolio & -.07 & -.21 & .80 & -.01 & -.09 \\
\hline Real estate and portfolio risk management & .17 & .36 & .46 & -.60 & .13 \\
\hline Indirect real estate investment vehicles & .29 & .69 & -.13 & .05 & -.13 \\
\hline Demographic changes affecting real estate & .82 & .05 & .05 & .05 & -.17 \\
\hline Technological factors affecting real estate & .86 & -.07 & .02 & -.06 & .14 \\
\hline Regulatory changes affecting real estate & .76 & .17 & -.23 & .12 & -.03 \\
\hline Real estate investment strategies & .43 & .38 & -.24 & -.47 & .23 \\
\hline Percentage variation explained & $22.8 \%$ & $14.9 \%$ & $12.5 \%$ & $10.3 \%$ & $8.6 \%$ \\
\hline Cumulative percentage variation explained & $22.8 \%$ & $37.7 \%$ & $50.2 \%$ & $60.5 \%$ & $69.1 \%$ \\
\hline
\end{tabular}

research priorities was also consistent with the lesser correlation seen in the general real estate research priorities.

In particular, the higher priority in the U.S. survey given to appraisal issues (priority 6-7) compared to the other three surveys (priority 12-19) reflects concerns over the use of the NCREIF Index as a customized real estate portfolio benchmark, particularly in comparison to the U.K. Investment Property Databank (IPD) indices and the Australia
Property Council of Australia (PCA) indices and the higher level of academic awareness concerning the effectiveness of using valuations as a proxy for real estate market performance. Similarly, the lesser priority in the U.K., Australia and Germany surveys given to the impact of e-commerce on real estate demand (priority 23-27) compared to the U.S. survey (priority 12) reflects the timing of the surveys (2000 versus 2001-03) and the greater technological penetration in the real estate sector since the U.S. survey in 2000. 
Exhibit 5 (continued)

PCA Factor Weights for General Real Estate Research Priorities

\begin{tabular}{|c|c|c|c|c|c|c|}
\hline \multirow[b]{2}{*}{ Topic } & \multicolumn{6}{|l|}{ Dimensions } \\
\hline & 1 & 2 & & 3 & 4 & 5 \\
\hline \multicolumn{7}{|c|}{ Panel C: Germany: Five dimensions accounting for $70.2 \%$ of variation } \\
\hline The role of real estate in a mixed-asset portfolio & -.08 & -.03 & & .42 & -.16 & .76 \\
\hline Diversification within real estate portfolios & .10 & .59 & & .63 & -.18 & -.11 \\
\hline Macroeconomic factors affecting real estate & .74 & .24 & & .14 & -.11 & -.05 \\
\hline Microeconomic factors affecting real estate & .18 & .82 & & .07 & -.08 & .11 \\
\hline Performance measures of real estate & .29 & .22 & & -.04 & .67 & .08 \\
\hline Role of international real estate in a portfolio & .05 & .06 & & .77 & .38 & .21 \\
\hline Real estate and portfolio risk management & -.16 & .72 & & -.01 & .26 & -.09 \\
\hline Indirect real estate investment vehicles & .23 & .03 & & -.14 & .12 & .82 \\
\hline Demographic changes affecting real estate & .80 & -.08 & & -.02 & .10 & .27 \\
\hline Technological factors affecting real estate & .82 & -.04 & & -.06 & .08 & .01 \\
\hline Regulatory changes affecting real estate & .08 & .51 & & -.55 & .38 & .06 \\
\hline Real estate investment strategies & -.13 & -.05 & & .08 & .75 & -.06 \\
\hline Percentage variation explained & $21.2 \%$ & $15.4 \%$ & & $14.0 \%$ & $11.3 \%$ & $8.4 \%$ \\
\hline Cumulative percentage variation explained & $21.2 \%$ & $36.5 \%$ & & $50.5 \%$ & $61.8 \%$ & $70.2 \%$ \\
\hline \multicolumn{7}{|c|}{ Panel D: U.S.: Four dimensions accounting for $69.8 \%$ of variation } \\
\hline The role of real estate in a mixed-asset portfolio & .21 & & -.03 & & .16 & .89 \\
\hline Diversification within real estate portfolios & .66 & & .11 & & .09 & .23 \\
\hline Macroeconomic factors affecting real estate & .36 & & .70 & & .31 & -.15 \\
\hline Microeconomic factors affecting real estate & .46 & & .24 & & -.04 & .55 \\
\hline Performance measures of real estate & .68 & & .14 & & -.06 & .31 \\
\hline Role of international real estate in a portfolio & -.22 & & -.73 & & .30 & .26 \\
\hline Real estate and portfolio risk management & .44 & & .73 & & -.28 & .05 \\
\hline Indirect real estate investment vehicles & .08 & & .23 & & -.83 & .23 \\
\hline Demographic changes affecting real estate & .79 & & .12 & & .28 & .09 \\
\hline Technological factors affecting real estate & .60 & & -.05 & & .67 & -.17 \\
\hline Regulatory changes affecting real estate & .76 & & .20 & & .23 & .12 \\
\hline Real estate investment strategies & .71 & & .01 & & .01 & .08 \\
\hline Percentage variation explained & $38.3 \%$ & & $12.0 \%$ & & $10.2 \%$ & $9.3 \%$ \\
\hline Cumulative percentage variation explained & $38.3 \%$ & & $50.2 \%$ & & $60.5 \%$ & $69.8 \%$ \\
\hline
\end{tabular}

\section{Identifying Dimensions in Specific Real Estate Research Priorities}

From the twenty-seven specific real estate research topics, Exhibit 8 indicates the PCA results for the number of underlying real estate "dimensions" and the level of total variation explained in the four surveys. ${ }^{4}$ The PCA results were generally consistent, identifying 8-9 dimensions and accounting for $69.3 \%-76.9 \%$ of the total variation in each case.
With 8-9 dimensions identified per survey, the vast majority of dimensions were able to be given a real estate interpretation; particularly the more significant dimensions that accounted for a large component of the total variation explained. The lack of a real estate interpretation for some dimensions was most evident in the higher order dimensions for the Germany and U.S. surveys.

The real estate dimensions that dominated across the four surveys were: 


\section{Exhibit 6}

Specific Real Estate Research Priorities

\begin{tabular}{|c|c|c|c|c|c|c|c|c|}
\hline \multirow[b]{2}{*}{ Specific Real Estate Research Topic } & \multicolumn{2}{|l|}{ U.K. } & \multicolumn{2}{|c|}{ Australia } & \multicolumn{2}{|c|}{ Germany } & \multicolumn{2}{|l|}{ U.S. } \\
\hline & Score & Rank & Score & Rank & Score & Rank & Score & Rank \\
\hline Taxation factors affecting real estate & 3.73 & 1 & 3.56 & 8 & 3.93 & 2 & 2.16 & 27 \\
\hline Real estate liquidity compared to other asset classes & 3.72 & 2 & 3.47 & 9 & 2.72 & 19 & 3.02 & 19 \\
\hline Existence and predictability of real estate cycles & 3.70 & 3 & 3.58 & 7 & 3.72 & 5 & 3.63 & 4 \\
\hline Diversification within a mixed-asset portfolio & 3.65 & 4 & 3.77 & 3 & 3.48 & 9 & 3.22 & 9 \\
\hline Diversification within a real estate portfolio & 3.62 & 5 & 3.64 & 5 & 3.69 & 6 & 3.16 & 13 \\
\hline Impact of capital flows in and out of real estate markets & 3.46 & 6 & 3.84 & 1 & 3.48 & 9 & 3.82 & 1 \\
\hline Passive versus active investment strategies & 3.43 & 7 & 3.34 & 13 & 3.21 & 14 & 2.98 & 21 \\
\hline Role of indirect real estate in a mixed-asset portfolio & 3.42 & 8 & 3.83 & 2 & 3.41 & 11 & 2.94 & 23 \\
\hline Forecasting methodologies for markets, results, returns & 3.27 & 9 & 3.59 & 6 & 4.21 & 1 & 3.20 & 10 \\
\hline Real estate investment in primary versus secondary markets & 3.25 & 10 & 3.02 & 20 & 2.48 & 23 & 3.13 & 15 \\
\hline Real estate disposal and exit strategies & 3.23 & 11 & 3.41 & 10 & 3.90 & 3 & 3.81 & $\mathbf{2}$ \\
\hline Economic versus geographic versus real estate type diversification & 3.21 & 12 & 3.25 & 17 & 3.17 & 15 & 3.41 & 5 \\
\hline Effects of structural changes in employment demand on real estate investment & 3.14 & 13 & 3.14 & 19 & 3.24 & 12 & 3.14 & 14 \\
\hline Effects of appraisal practices on individual portfolio returns & 3.13 & 14 & 3.25 & 17 & 3.24 & 12 & 3.37 & 6 \\
\hline Supply side constraints & 3.09 & 15 & 3.34 & 14 & 2.62 & 21 & 3.13 & 16 \\
\hline Impact of appraisal lags and biases on real estate indices & 3.08 & 16 & 3.27 & 16 & 2.72 & 19 & 3.28 & 7 \\
\hline Real estate's market capitalization compared to other asset classes & 3.04 & 17 & 2.98 & 22 & 3.03 & 16 & 3.04 & 18 \\
\hline Effects of an aging population on real estate investment & 2.95 & 18 & 3.36 & 12 & 2.83 & 17 & 3.23 & 8 \\
\hline Individual real estate-type market studies & 2.94 & 19 & 3.00 & 21 & 3.55 & 8 & 3.10 & 17 \\
\hline Environmental regulations regarding contaminated land & 2.92 & 20 & 2.88 & 23 & 2.45 & 24 & 3.20 & 10 \\
\hline Effect of country/currency risk on international real estate investment & 2.92 & 20 & 3.31 & 15 & 3.79 & 4 & 3.01 & 20 \\
\hline Effect of management fees on portfolio performance & 2.91 & 22 & 3.36 & 11 & 2.83 & 17 & 3.66 & 3 \\
\hline Effect of e-commerce on real estate demand & 2.76 & 23 & 2.64 & 27 & 2.31 & 27 & 3.19 & 12 \\
\hline Foreign investment restrictions & 2.73 & 24 & 2.75 & 25 & 3.66 & 7 & 2.62 & 26 \\
\hline REITs as a proxy for direct real estate investment & 2.70 & 25 & 3.75 & 4 & 2.41 & 26 & 2.96 & 22 \\
\hline Effects of changing household structure on real estate investment & 2.51 & 26 & 2.81 & 24 & 2.45 & 24 & 2.73 & 24 \\
\hline Effects of immigration patterns on real estate investment & 2.38 & 27 & 2.66 & 26 & 2.52 & 22 & 2.70 & 25 \\
\hline Overall average score & 3.14 & & 3.29 & & 3.15 & & 3.14 & \\
\hline
\end{tabular}

Note: Top three priorities for each country are given in bold.

1. Changing real estate environment (found in 3 of the 4 surveys);

2. Specific real estate market dynamics (found in 3 of the 4 surveys);

3. Diversification in portfolio (found in all 4 surveys); and

4. International real estate investment (found in 3 of the 4 surveys).

The changing real estate environment was the dominant real estate dimension in all surveys (except the Germany survey), accounting for 9.9\%$14.9 \%$ of the total variation explained and being

\section{Exhibit 7}

Specific Real Estate Research Priorities: Cross-Country Correlations

\begin{tabular}{lllll}
\hline & U.K. & Australia & Germany & U.S. \\
\hline U.K. & 1.00 & & & \\
Australia & $0.71^{*}$ & 1.00 & & \\
Germany & $0.52^{*}$ & $0.46^{*}$ & 1.00 & \\
U.S. & 0.18 & 0.28 & 0.07 & 1.00 \\
\hline
\end{tabular}

Note:

* Significant correlation $(p<5 \%)$. 


\section{Exhibit 8 \\ Specific Real Estate Research Priorities: PCA Dimensions}

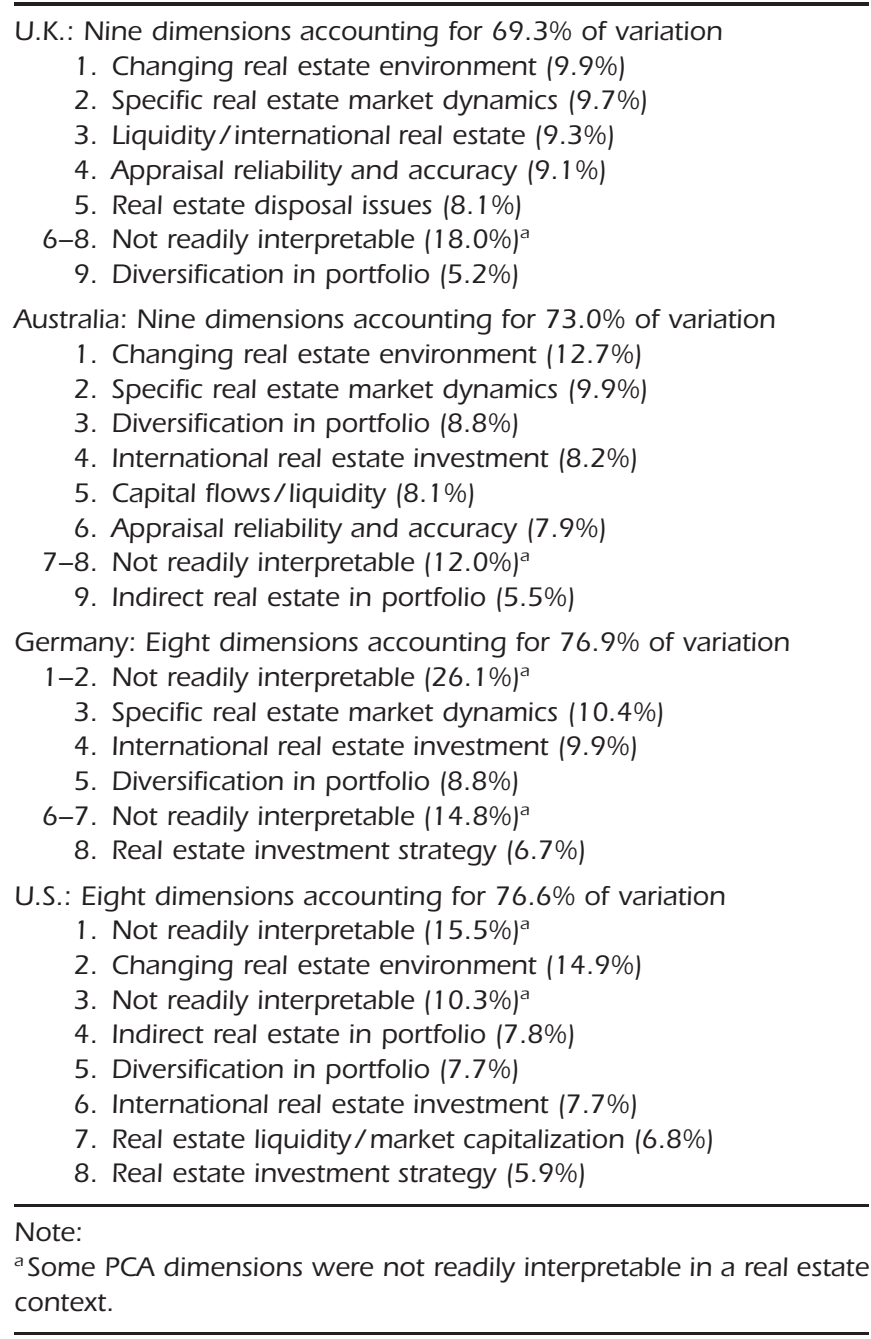

the most important real estate dimension in three of the four surveys.

\section{Conclusion}

These surveys have clearly identified the general and specific real estate research priorities for real estate fund managers in the U.S., U.K., Australia and Germany. These priorities should be useful for real estate fund managers, as well as to real estate researchers regarding potential priority real estate research topics suitable for research funding from leading real estate industry groups such as the Pension Real Estate Association (U.S.), Real Estate Research Institute (U.S.), Royal Institution of
Chartered Surveyors (U.K.), Investment Property Forum (U.K.), German Society of Property Researchers (Germany) and Property Council of Australia (Australia).

The role of real estate in a mixed-asset portfolio and real estate and portfolio risk management figure prominently amongst the general real estate research priorities. Many of the dimensions identified using PCA have a clear real estate interpretation; particularly relating to the changing real estate environment, strategic real estate issues and the role of real estate in the portfolio. Importantly, when comparing the results of the four different surveys, there is a much closer alignment of the real estate research priorities in the U.K., Australia and Germany than found in the U.S.

It is hoped that the results of this research on the real estate research priorities across countries will be the catalyst to future research initiatives in this crucial area of real estate research for members of ARES, ERES, PRRES and AsRES.

\section{Endnotes}

1. The Germany survey (Schulte, Newell and Worzala, 2003) was administered in German.

2. The U.S. survey (Worzala, Gilliland and Gordon, 2002) used a seven-point rating scale, which was standardized to a fivepoint rating scale to ensure consistency with the U.K., Australia and Germany surveys.

3. Compared to the U.S. survey, the U.K., Australia and Germany surveys involved a broader range of real estate participants (see Exhibit 1), including real estate fund managers, real estate advisors and consultants, real estate companies and real estate academics. For consistency, only real estate fund managers were assessed in this research.

4. PCA factor weights for the underlying dimensions are not presented for the specific real estate research priorities due to the large size of the table; factor weights for the four country analyses if needed can be obtained from the authors.

\section{References}

Adair, A., N. Crosby, L.C. Lim and C. Watkins, The Contribution of the RICS Cutting Edge Conference to Commercial Real Estate Research, Journal of Property Research, 2003, 20:1, 91115.

Crosby, N., Future Directions and Challenges for Valuation Research and Practice, Pacific Rim Property Research Journal, 2000, 6:1, 3-11. 
Everitt, B. and G. Dunn, Applied Multivariate Data Analysis, London: Arnold, 2001.

Jaffe, A., The Costs of Ignoring Institutional Factors in International Property Research, Australian Land Economics Review, 1998, 4:2, 3-9.

Jones Lang LaSalle, Germany's Fourth Financial Market Promotion Act, London: Jones Lang LaSalle, 2002.

Lusht, K., Future Directions in Real Estate Research, Journal of Property Valuation and Investment, 1993, 11:4, 327-37.

Newell, G., P. Acheampong and E. Worzala, Property Research Priorities in Australia, Pacific Rim Property Research Journal, 2002, 8:2, 127-39.

Newell, G., P. McAllister and E. Worzala, Property Research Priorities in the U.K., Journal of Property Investment and Finance, 2003, 22:3, 269-82.

Parker, D., An Institutional Perspective on Property Research, Pacific Rim Property Research Journal, 2001, 7:1, 3-17.

Schulte, K., G. Newell and E. Worzala, Property Research Priorities in Germany, Paper presented at ERES Conference, 2003, Helsinki.
Souza, L., Academic and Applied Real Estate Research: 'As Two Worlds Collide' or 'As Two Worlds Divide,' Journal of Real Estate Portfolio Management, 2000, 6:1, 97-100.

Steinert, M. and S. Crowe, Global Real Estate Investment: Characteristics, Portfolio Allocation and Future Trends, Pacific Rim Property Research Journal, 2001, 7:4, 223-39.

Webb, J., A Global View of Real Estate Education and Research: Past, Present and Future, Australian Land Economics Review, 1997, 3:2, 3-7.

Winograd, B., Research I'd Like to Read, Journal of Real Estate Portfolio Management, 1999, 5:2, 195-97.

Worzala, E., Bridging the Practical/Academic Divide in Real Estate, Pacific Rim Property Research Journal, 2002, 8:1, 314.

Worzala, E., D. Gilliland and J. Gordon, Real Estate Research Needs of the Plan Sponsor Community, Journal of Real Estate Portfolio Management, 2002, 8:1, 65-78.

Ziering, B. and E. Worzala, The Real Estate Interests of the Plan Sponsor Community: Survey Results, Journal of Real Estate Research, 1997, 13:2, 115-43. 